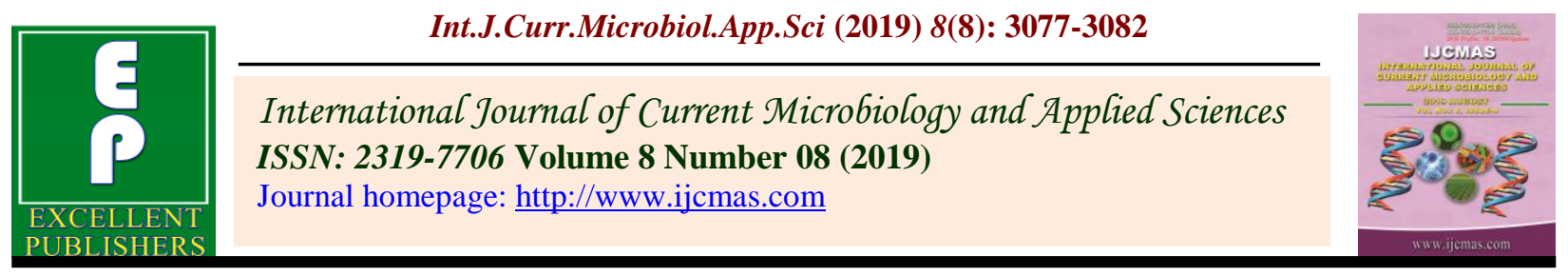

Original Research Article

https://doi.org/10.20546/ijcmas.2019.808.356

\title{
Effect of Vermicompost and Zinc Application on Growth and Yield Attribute of Maize Crop
}

\author{
Rakesh Khatik*, D.P. Singh, H.K. Jain, K.K. Yadav, R.S. Choudhary and R.N. Bunker \\ Department of Soil Science and Agricultural Chemistry, Rajasthan College of Agriculture, \\ MPUAT, Udaipur, India \\ *Corresponding author
}

\begin{tabular}{|l|}
\hline Ke y w or d s \\
Maize (Zea mays \\
L.), Gramineae \\
family \\
\hline Article Info \\
\hline $\begin{array}{l}\text { Accepted: } \\
\text { 25 July 2019 } \\
\text { Available Online: } \\
\text { 10 August } 2019\end{array}$ \\
\hline
\end{tabular}

A B S T R A C T

A field experiment was conducted at Instructional Farm, Rajasthan College of Agriculture, MPUAT, Udaipur, Rajasthan during 2018 to Effect of vermicompost and zinc application on growth and yield attribute of maize crop. The experiment was laid out in a randomized block design, comprising vermicompost and zinc and their combination, viz., $\mathrm{T}_{1}$ control, $\mathrm{T}_{2}$ vermicompost $\left(1.5 \mathrm{t} \mathrm{ha}^{-1}\right)+\operatorname{zinc}\left(0 \mathrm{~kg} \mathrm{ha}^{-1}\right)$, $\mathrm{T}_{3}$ vermicompost $\left(1.5 \mathrm{t} \mathrm{ha}^{-1}\right)+\operatorname{zinc}\left(2.5 \mathrm{~kg} \mathrm{ha}^{-1}\right), \mathrm{T}_{4}$ vermicompost $\left(1.5 \mathrm{t} \mathrm{ha}^{-1}\right)+$ zinc $\left(5.0 \mathrm{~kg} \mathrm{ha}^{-1}\right), \quad \mathrm{T}_{5}$ vermicompost $\left(3.0 \mathrm{t} \mathrm{ha}^{-1}\right)+\operatorname{zinc}\left(0 \mathrm{~kg} \mathrm{ha}{ }^{-1}\right), \mathrm{T}_{6}$ vermicompost $\left(3.0 \mathrm{t} \mathrm{ha}^{-1}\right)+\operatorname{zinc}\left(2.5 \mathrm{~kg} \mathrm{ha}^{-1}\right), \mathrm{T}_{7}$ vermicompost $\left(3.0 \mathrm{tha}^{-1}\right)+$ zinc $\left(5.0 \mathrm{~kg} \mathrm{ha}^{-1}\right), \mathrm{T}_{8}$ vermicompost $\left(4.5 \mathrm{tha}^{-1}\right)+\operatorname{zinc}\left(0 \mathrm{~kg} \mathrm{ha}^{-1}\right), \mathrm{T}_{9}$ vermicompost $(4.5$ $\left.\mathrm{t} \mathrm{ha}^{-1}\right)+\operatorname{zinc}\left(2.5 \mathrm{~kg} \mathrm{ha}^{-1}\right), \mathrm{T}_{10}$ vermicompost $\left(4.5 \mathrm{t} \mathrm{ha}^{-1}\right)+\operatorname{zinc}\left(5.0 \mathrm{~kg} \mathrm{ha}^{-1}\right)$, treatments replicated three times. The increased growth parameter such as chlorophyll content, plant height (30, 60 and at harvest), Leaf area index (30, 45 and 60 DAS) with the application of vermicompost $\left(4.5 \mathrm{t} \mathrm{ha}^{-1}\right)+\operatorname{zinc}\left(5.0 \mathrm{~kg} \mathrm{ha}^{-1}\right)$. The application of vermicompost $\left(4.5 \mathrm{t} \mathrm{ha}^{-1}\right)+$ zinc $\left(5.0 \mathrm{~kg} \mathrm{ha}^{-1}\right)$ increased number of grain per cob (457.09), weight of grain per cob (95.04 g), seed index (33.65 g) seed yield (3896.33 $\left.\mathrm{kg} \mathrm{ha}^{-1}\right)$, Stover yield $\left(5415.13 \mathrm{~kg} \mathrm{ha}^{-1}\right)$ and biological yield $\left(9311.46 \mathrm{~kg} \mathrm{ha}^{-1}\right)$ as compared to control.

\section{Introduction}

Maize is an important cereals crop ranking $3^{\text {rd }}$ after wheat and rice in respect of area and production. Maize (Zea mays L.) belongs to Gramineae family; it is considered as the native to Central America \& Mexico. Maize is one of most important cereal crop in term of world agriculture economy both as food for man and feed for animal. It is a miracle crop as its grain yield potential (GYP) is twice as high as compared to other cereal crops (Tollenaar and Lee, 2002). There is no cereal on earth which has so immense potentiality and that is why it is also called "queen of cereals". Maize is grown in almost all the states of India. Maize grain contains about $10 \%$ protein, $4 \%$ oil, $70 \%$ carbohydrate $2.3 \%$ crude fiber, $10.4 \%$ aluminizes, $1.4 \%$ ash. Maize protein 'Zein' is rich in tryptophan and 
lysine, the two essential amino acids. Being highly cross pollinated, maize has become highly polymorphic through the course of natural and domesticated evolution and thus contains enormous genetic variability. Maize may also have the capacity to tolerate salinity stress (Paterniani, 2009). Maize crop furnishes huge quantities of green fodder for cattle.

Vermicompost is a good substitute to commercial fertilizers and has more $\mathrm{N}, \mathrm{P}$ and $\mathrm{K}$ content than the normal heap manure (Srivastava and Beohar, 2004). The application of vermicompost helps to improves and conserves the fertility of soil. Vermicompost imparts a dark colour of the soil and thereby help to maintain the temperature of soil. Vermicompost is one of the manure used by the farmer in growing crops because of early availability and presence of almost all the nutrients required by plants.

Zinc is an essential element for plant growth, crop yield and quality. When the supply of plant-available zinc is insufficient, crop yields are reduced and the quality of crop products is frequently impaired (Alloway et al., 2003). Natural levels of zinc in the soil range from 10 to $300 \mathrm{mg} \mathrm{kg}^{-1}$ with an average of $50 \mathrm{mg} \mathrm{kg}^{-1}$ (Mulligan et al., 2001). It is estimated that 30 per cent of the world's cultivated soils are deficient in zinc (Suzuki et al., 2006) and Grain-yield reductions of upto 80 per cent along with reduced grain zinc level have been observed under zinc deficiency (Cakmak et al., 1998)

\section{Materials and Methods}

A field experiment was conducted during kharif season of 2018 at Instructional Farm, Rajasthan College of Agriculture, MPUAT, Udaipur, Rajasthan. The soil was sandy clay loamy. The soil had $\mathrm{pH}$ value of 8.10 , medium in available nitrogen (338.32 $\left.\mathrm{kg} \mathrm{N} \mathrm{ha}^{-1}\right)$, medium in available phosphorus $(28.32 \mathrm{~kg}$ $\left.\mathrm{P}_{2} \mathrm{O}_{5} \mathrm{ha}^{-1}\right)$ and high in potassium $(352.68 \mathrm{~kg}$ $\mathrm{K}_{2} \mathrm{O} \mathrm{ha}^{-1}$ ). The experiment was laid out in a randomized block design, comprising vermicompost and zinc and their combination, viz., $\mathrm{T}_{1}$ control, $\mathrm{T}_{2}$ vermicompost $\left(1.5 \mathrm{tha}^{-1}\right)+$ zinc $\left(0 \mathrm{~kg} \mathrm{ha}^{-1}\right), \mathrm{T}_{3}$ vermicompost $\left(1.5 \mathrm{tha}^{-1}\right)+$ zinc $\left(2.5 \mathrm{~kg} \mathrm{ha}^{-1}\right), \mathrm{T}_{4}$ vermicompost $\left(1.5 \mathrm{t} \mathrm{ha}^{-1}\right)$ $+\operatorname{zinc}\left(5.0 \mathrm{~kg} \mathrm{ha}^{-1}\right), \mathrm{T}_{5}$ vermicompost $(3.0 \mathrm{t}$ $\left.\mathrm{ha}^{-1}\right)+$ zinc $\left(0 \mathrm{~kg} \mathrm{ha}^{-1}\right), \mathrm{T}_{6}$ vermicompost $(3.0 \mathrm{t}$ $\left.\mathrm{ha}^{-1}\right)+\operatorname{zinc}\left(2.5 \mathrm{~kg} \mathrm{ha}^{-1}\right), \mathrm{T}_{7}$ vermicompost $\left(3.0 \mathrm{t} \mathrm{ha}^{-1}\right)+$ zinc $\left(5.0 \mathrm{~kg} \mathrm{ha}^{-1}\right), \mathrm{T}_{8}$ vermicompost $\left(4.5 \mathrm{tha}^{-1}\right)+\operatorname{zinc}\left(0 \mathrm{~kg} \mathrm{ha}^{-1}\right), \mathrm{T}_{9}$ vermicompost $\left(4.5 \mathrm{t} \mathrm{ha}^{-1}\right)+$ zinc $\left(2.5 \mathrm{~kg} \mathrm{ha}^{-1}\right)$, $\mathrm{T}_{10}$ vermicompost $\left(4.5 \mathrm{t} \mathrm{ha}^{-1}\right)+\operatorname{zinc}(5.0 \mathrm{~kg}$ $\left.\mathrm{ha}^{-1}\right)$, treatments replicated three times. Seed rate $25 \mathrm{~kg} \mathrm{ha}^{-1}$ of maize variety 'PHEM-2' was used in this study. Whole amount of vermicompost as per treatment was broadcasted uniformly at the time of sowing and. The recommended dose of nitrogen (120 $\left.\mathrm{kg} \mathrm{ha}^{-1}\right)$ through urea, phosphorus $\left(60 \mathrm{~kg} \mathrm{ha}^{-1}\right)$ through DAP, potassium (40 kg ha-1) through MOP and zinc through $\mathrm{ZnSO}_{4} .7 \mathrm{H}_{2} \mathrm{O}$ were applied as basal as per treatments.

\section{Results and Discussion}

\section{Growth parameter}

Application of vermicompost $\left(4.5 \mathrm{t} \mathrm{ha}^{-1}\right)+$ zinc $\left(5.0 \mathrm{~kg} \mathrm{ha}^{-1}\right)$ significantly increased plant height at 30, 60 DAS and at harvest as compared to control. The application of vermicompost $\left(4.5 \mathrm{t} \mathrm{ha}^{-1}\right)+\operatorname{zinc}\left(5.0 \mathrm{~kg} \mathrm{ha}^{-1}\right)$ significantly increased of leaf area index at 30 , 45 and 60 DAS and Chlorophyll content at 45 DAS as compared to control. Vermicompost and farmyard manure are rich source of macro-and micro-nutrients and growth hormones, which not only supply essential nutrients to the soil but also improve the physico-chemical and biological properties of the soil (Sharma et al., 2005; Rawat and Pareek, 2003). The improved physicochemical properties and slow release of 
nutrients over longer period with the uses of organic sources might be responsible for better growth of popcorn plants with FYM and vermicompost application. The improvement in plant height and LAI with the use of organic sources consequently enhanced the dry matter/plant. These results corroborate the findings of Jayaprakash et al., (2004) and Kumar et al., (2007). This may be due to the fact that in addition to the involvement of zinc in many enzymatic functions within plant it also play hole in the chlorophyll formation and acts as structural constituent of chloroplast and increased the chlorophyll content. The magnificent role of zinc in increasing the metabolic and physiological activity of the plants is of preponderant importance as it influenced the nitrogen metabolism, chlorophyll formation. The application of zinc up to $5.0 \mathrm{~kg} \mathrm{ha}^{-1}$ significantly increased plant height and leaf area index at all the stages of observation compared to control the favorable effect of applied zinc on plant height and leaf area index may be due to its stimulatory effect on most of the physiological and metabolic processes of plants. Zinc is a constituent of carbonic anhydrase (an enzyme promotes carbon dioxide assimilation pathway in $\mathrm{C}_{4}$ cycle of photosynthesis) and there is direct relationship between carbonic anhydrase and photosynthetic carbon dioxide assimilation on growth of plants. It is well known fact that zinc is involve in the protein synthesis, biosynthesis of Indole 3-acetic acid (a growth hormone, involved in cell division and cell elongation), hence increased plant height and leaf area index. It also performs many catalytic functions in the plant besides transformation of carbohydrates and chlorophyll synthesis. The significant response to zinc in terms of improvement in plant height is further supported by the fact that soil of the experimental field was low in zinc status and its early supply corrected the deficiency and considerably improved the crop growth. The finding of this investigation confirm the observation of earlier worker, Hossaini et al., (2007), Meena et al., (2013), Preetha et al., (2014) Jangir et al., (2015) and Gupta et al., (2018).

\section{Yield attribute}

Application of vermicompost $\left(4.5 \mathrm{t} \mathrm{ha}^{-1}\right)+$ zinc $\left(5.0 \mathrm{~kg} \mathrm{ha}{ }^{-1}\right)$ significantly increased number of grain per cob (457.09), weight of grain per cob (95.04 g), seed index (33.65) seed yield (3896.33 $\left.\mathrm{kg} \mathrm{ha}^{-1}\right)$, stover yield $\left(5415.13 \mathrm{~kg} \mathrm{ha}^{-1}\right)$ and biological yield $\left(9311.46 \mathrm{~kg} \mathrm{ha}{ }^{-1}\right)$. The application of vermicompost $4.5 \mathrm{t} \mathrm{ha}^{-1}$ with zinc up to $5 \mathrm{~kg}$ $\mathrm{ha}^{-1}$ significantly increased yield and yield attributes. The considerable improvement in grain yield owing to application of organic sources might be attributed to the fact that organic sources of nutrients had the positive effect on yield attributes and cumulative effect of yield attributes mainly responsible for higher productivity with the application of organic sources. The increase in grain and stover yield, weight of cob plant ${ }^{-1}$, number of grains $\operatorname{cob}^{-1}$ and test weight of maize due to application of vermicompost might be attributed mainly to higher content of available nutrients in vermicompost, presence of beneficial micro flora such as nitrogen fixers, phosphate solubalizers, VAM fungi and higher activity of dehydrogenase enzyme in soil. The finding of this investigation close conformity with finding of Ramesh et al., (2008) and Meena et al., (2013).

The application of $5 \mathrm{~kg}$ zinc ha- 1 significantly increased yield and its attributes viz., number of cob-1, number of grain cob-1, seed index, weight of grain cob-1 compared to control. The increase in yield attributes might also be in biosynthesis of indole acetic acid and especially due to its role in initiation of reproductive parts and partitioning of photosynthates toward them, which resulted in better flowering and fruiting. 
Int.J.Curr.Microbiol.App.Sci (2019) 8(8): 3077-3082

Table.1 Effect of vermicompost and zinc application on growth parameters of maize

\begin{tabular}{|l|c|c|c|c|c|c|c|}
\hline & \multicolumn{3}{|c|}{ Tlant height (cm) } & \multicolumn{3}{c|}{ Leaf Area Index } & $\begin{array}{c}\text { Chlorophyll } \\
\text { content } \text { (mg g-1 }^{-1}\end{array}$ \\
\hline & 30 & 60 & At & 30 & 45 & 60 & $\begin{array}{c}\text { at } 45 \\
\text { DAS }\end{array}$ \\
\hline & DAS & DAS & harvest & DAS & DAS & DAS & DAts \\
\hline$T_{1}$ Control & 71.14 & 171.21 & 203.11 & 0.98 & 1.29 & 2.76 & 1.56 \\
\hline$T_{2} \mathrm{VC}(1.5 \mathrm{t})+\mathrm{Zn}(0 \mathrm{~kg})$ & 74.16 & 174.02 & 206.89 & 1.12 & 1.42 & 2.94 & 1.61 \\
\hline $\mathrm{T}_{3} \mathrm{VC}(1.5 \mathrm{t})+\mathrm{Zn}(2.5 \mathrm{~kg})$ & 76.19 & 175.68 & 210.77 & 1.18 & 1.47 & 3.05 & 1.66 \\
\hline $\mathrm{T}_{4} \mathrm{VC}(1.5 \mathrm{t})+\mathrm{Zn}(5.0 \mathrm{~kg})$ & 79.26 & 177.41 & 213.52 & 1.25 & 1.51 & 3.17 & 1.71 \\
\hline $\mathrm{T}_{5} \mathrm{VC}(3.0 \mathrm{t})+\mathrm{Zn}(0 \mathrm{~kg})$ & 80.58 & 178.98 & 216.13 & 1.31 & 1.58 & 3.30 & 1.76 \\
\hline $\mathrm{T}_{6} \mathrm{VC}(3.0 \mathrm{t})+\mathrm{Zn}(2.5 \mathrm{~kg})$ & 82.19 & 180.48 & 219.58 & 1.37 & 1.63 & 3.41 & 1.82 \\
\hline $\mathrm{T}_{7} \mathrm{VC}(3.0 \mathrm{t})+\mathrm{Zn}(5.0 \mathrm{~kg})$ & 85.03 & 182.37 & 222.66 & 1.43 & 1.69 & 3.53 & 1.87 \\
\hline $\mathrm{T}_{8} \mathrm{VC}(4.5 \mathrm{t})+\mathrm{Zn}(0 \mathrm{~kg})$ & 87.84 & 183.77 & 225.16 & 1.49 & 1.76 & 3.65 & 1.93 \\
\hline $\mathrm{T}_{9} \mathrm{VC}(4.5 \mathrm{t})+\mathrm{Zn}(2.5 \mathrm{~kg})$ & 91.38 & 185.94 & 227.92 & 1.57 & 1.79 & 3.77 & 2.01 \\
\hline $\mathrm{T}_{10} \mathrm{VC}(4.5 \mathrm{t})+\mathrm{Zn}(5.0 \mathrm{~kg})$ & 93.72 & 188.68 & 230.36 & 1.64 & 1.84 & 3.91 & 2.08 \\
\hline $\mathrm{SE} . \mathrm{m} \pm$ & 0.44 & 0.47 & 0.74 & 0.02 & 0.01 & 0.03 & 0.01 \\
\hline $\mathrm{CD}(\mathrm{P}=0.05)$ & 1.30 & 1.39 & 2.20 & 0.05 & 0.02 & 0.10 & 0.04 \\
\hline
\end{tabular}

Table.2 Effect of vermicompost and zinc application on yield attributes of maize

\begin{tabular}{|c|c|c|c|c|c|c|}
\hline Treatment & $\begin{array}{c}\text { No. of } \\
\text { seeds } \\
\text { per cob }\end{array}$ & $\begin{array}{l}\text { Weight } \\
\text { of grain } \\
\text { cob }^{-1}\end{array}$ & $\begin{array}{c}\text { Seed } \\
\text { index } \\
(\mathrm{g})\end{array}$ & $\begin{array}{c}\text { Seed } \\
\text { yield }(\mathrm{kg} \\
\left.\text { ha }^{-1}\right)\end{array}$ & $\begin{array}{c}\text { Stover } \\
\text { yield (kg } \\
\left.\text { ha }^{-1}\right)\end{array}$ & $\begin{array}{c}\text { Biological } \\
\text { yield (kg } \\
\text { ha }^{-1} \text { ) }\end{array}$ \\
\hline $\mathrm{T}_{1}$ Control & 308.12 & 77.46 & 19.09 & 2110.00 & 3270.00 & 5380.00 \\
\hline $\mathrm{T}_{2} \mathrm{VC}(1.5 \mathrm{t})+\mathrm{Zn}(0 \mathrm{~kg})$ & 346.88 & 81.47 & 20.73 & 2628.00 & 4016.00 & 6644.00 \\
\hline$T_{3} V C(1.5 \mathrm{t})+\mathrm{Zn}(2.5 \mathrm{~kg})$ & 352.16 & 82.95 & 21.86 & 2764.00 & 4168.00 & 6932.00 \\
\hline $\mathrm{T}_{4} \mathrm{VC}(1.5 \mathrm{t})+\mathrm{Zn}(5.0 \mathrm{~kg})$ & 365.22 & 84.47 & 23.55 & 2882.00 & 4294.00 & 7176.00 \\
\hline $\mathrm{T}_{5} \mathrm{VC}(3.0 \mathrm{t})+\mathrm{Zn}(0 \mathrm{~kg})$ & 389.12 & 86.68 & 24.95 & 3066.00 & 4511.00 & 7577.00 \\
\hline $\mathrm{T}_{6} \mathrm{VC}(3.0 \mathrm{t})+\mathrm{Zn}(2.5 \mathrm{~kg})$ & 395.31 & 88.11 & 26.56 & 3246.33 & 4716.00 & 7962.33 \\
\hline $\mathrm{T}_{7} \mathrm{VC}(3.0 \mathrm{t})+\mathrm{Zn}(5.0 \mathrm{~kg})$ & 405.03 & 89.97 & 28.43 & 3372.00 & 4839.00 & 8211.00 \\
\hline $\mathrm{T}_{8} \mathrm{VC}(4.5 \mathrm{t})+\mathrm{Zn}(0 \mathrm{~kg})$ & 440.13 & 91.64 & 29.62 & 3494.00 & 4912.00 & 8406.00 \\
\hline $\mathrm{T}_{9} \mathrm{VC}(4.5 \mathrm{t})+\mathrm{Zn}(2.5 \mathrm{~kg})$ & 450.44 & 93.13 & 31.64 & 3645.33 & 5148.00 & 8793.33 \\
\hline $\mathrm{T}_{10} \mathrm{VC}(4.5 \mathrm{t})+\mathrm{Zn}(5.0 \mathrm{~kg})$ & 457.09 & 95.04 & 33.65 & 3896.33 & 5415.13 & 9311.46 \\
\hline SE.m \pm & 1.25 & 0.44 & 0.36 & 31.93 & 22.28 & 31.00 \\
\hline $\mathrm{CD}(\mathrm{P}=\mathbf{0 . 0 5})$ & 3.72 & 1.32 & 1.08 & 94.87 & 66.20 & 92.11 \\
\hline
\end{tabular}


Under such situation an increase in yield attributes and yield is quite natural. The crop efficiency estimated in terms of harvest index significantly increase with the application of zinc. The positive response of yield components of maize because of due to greater availability of zinc and metabolites for growth and development of reproductive structure which ultimately led to recognition of higher productivity of individual plant. The increased availability of zinc and photosynthates might have enhanced yield and yield attributes. The finding of present investigation are supported by Meena et al., (2013), Kumar et al., (2014), Singh et al., (2017) and Gupta et al., (2018).

On the basis of experimental finding, it can be concluded that, higher growth and yield of the kharif maize crop (var. PHEM-2) can be obtained with the combined application of vermicompost $\left(4.5 \mathrm{t} \mathrm{ha}^{-1}\right)+\operatorname{zinc}\left(5.0 \mathrm{~kg} \mathrm{ha}^{-1}\right)$ under sandy clay loam soil of sub humid region of Rajasthan.

\section{References}

Gupta, S., Swaroop, N., Thomas, T., Dawson, J. and Rao, S.P. 2018. Effect of different levels of phosphorus and zinc on physico-chemical properties of soil, growth and yield of maize (Zea mays L.). International Journal of Chemical Studies, 6(6): 2105-210

Hosseini, S.M., Maioun, M., Karimian, N., Rounaghi, A. and Emam, Y. 2007. Effect of zinc and boron interaction on plant growth and tissue nutrient concentration of corn. Journal Plant Nutrition, 30: 773-781.

Jangir, A., Singh, V., Srivastava, P.C., Ram, S. and Bhatnagar, A. 2015. Phosphorus and zinc uptake and protein, lysine and tryptophan contents in quality protein maize in relation to phosphorus and zinc fertilization in mollisol. Annals of Agricultural Research New Series,
36(1): 50-57.

Jayaprakash, T.C., Nagalikar, V.P., Pujari, B.T. and Shetty, R.A. 2004. Dry matter and its accumulation pattern in maize as influenced by organics and inorganics. Karnataka Journal of Agricultural Sciences 17(2): 327-29.

Kumar, P., Halepyati, A.S., Desai, B.K. and Pujari, B.T. 2007. Effect of integrated nutrient management on the productivity and nutrient uptake by maize (Zea mays L.). Karnataka Journal of Agricultural Sciences, 20(4): 833-34.

Kumar, R. and Bohra, J.S. 2014. Effect of NPKS and Zn application on growth, yield, economics and quality of baby corn. Archives of Agronomy and Soil Science, 60: 1193-1206.

Meena, B.P., Kumar, A., Meena, S.R., Dhar, S., Rana, D.S. and Rana, K.S. 2013. Effect of different organic sources and levels of nutrients on growth and yield behaviour of popcorn (Zea mays) and potato (Solanum tuberosum) sequence. Indian Journal of Agronomy, 58(4): 474-479.

Preetha, P.S. and Stalin, P. 2014. Response of maize to soil applied zinc fertilizer under varying available zinc status of soil. Indian Journal of Science and Technology, 7(7): 939-944.

Ramesh, P., Singh, M. and Subbarao, A. 2008. Organic farming its relevance to the Indian context. Current Science, 88: 561-569.

Rawat, S.S. and Pareek, R.G. 2003. Effect of FYM and NPK on yield and nutrient uptake for soil fertility in wheat. Annals of Agricultural Bioresource Research, 8(1): 17-19.

Sharma, V., Kanwar, K. and Dev, S.P. 2005. Efficiency of vermicompost for improving crop yield and nutrient uptake in wheat. Journal of Soils and Crops, 15(2): 269-73. 
Singh, S., Singh, V. and Mishra, P. 2017. Effect of NPK, boron and zinc on productivity and profitability of late sown kharif maize (Zea mays L.) in western Uttar Pradesh, India. Annals of Agricultural New Series, 38(3): 310313.

\section{How to cite this article:}

Rakesh Khatik, D.P. Singh, H.K Jain, K.K Yadav, R.S Choudhary and Bunker, R.N. 2019. Effect of Vermicompost and Zinc Application on Growth and Yield Attribute of Maize Crop. Int.J.Curr.Microbiol.App.Sci. 8(08): 3077-3082. doi: https://doi.org/10.20546/ijcmas.2019.808.356 